\title{
Strand-Specific Reverse Transcription PCR for Detection of Replicating SARS-CoV-2
}

Catherine A. Hogan, ChunHong Huang, Malaya K. Sahoo, Hannah Wang, Becky Jiang, Mamdouh Sibai, Marisa Holubar, Roshni Mathew, James Zehnder, Benjamin A. Pinsky

We developed an assay that detects minus-strand RNA as a surrogate for actively replicating severe acute respiratory syndrome coronavirus 2 . We detected minus-strand RNA in 41 persons with coronavirus disease up to 30 days after symptom onset. This assay might inform clinical decisionmaking about patient infectiousness.

$\mathrm{R}$ eal-time reverse transcription PCR (rRT-PCR) is the standard diagnostic method for coronavirus disease 2019, but it cannot differentiate between actively replicating and inactive virus. Active replication is a critical factor for infectiousness; however, its time course is difficult to estimate because of the typical 20-50 days before rRT-PCR negative conversion occurs $(1,2)$. PCR cycle threshold $\left(C_{t}\right)$ values might help physicians to determine a patient's infectiousness, but researchers have isolated replicating virus from patients with a wide range (28-33) of $C_{t}$ values (3-7). Given the stringent biosafety precautions needed for viral culturing of severe acute respiratory syndrome coronavirus 2 (SARS-CoV-2), physicians require additional diagnostic tools. Actively replicating virus produces minus-strand RNA intermediates that can be detected by PCR $(8,9)$. We developed and validated a 2-step strand-specific rRT-PCR for the detection of actively replicating SARS$\mathrm{CoV}-2$ and assessed its clinical performance.

\section{The Study}

We conducted standard nucleic acid and amplificaton testing at the Stanford Health Care Clinical Virology Laboratory (Stanford, CA, USA) using the Panther Fusion SARS-CoV-2 Assay (Hologic Inc., https://www.hologic.com), the Panther Aptima SARS-CoV-2 Assay (Hologic Inc.), or the in-house

Author affiliations: Stanford University School of Medicine, Stanford, California, USA (C.A. Hogan, C. Huang, M.K. Sahoo, H. Wang,

M. Holubar, R. Mathew, J. Zehnder, B.A. Pinsky); Stanford Health

Care, Stanford (C.A. Hogan, B. Jiang, M. Sibai, B.A. Pinsky)

DOI: https://doi.org/10.3201/eid2702.204168
rRT-PCR specific to the SARS-CoV-2 envelope gene (permitted by Emergency Use Authorization) $(10,11)$. We did not culture SARS-CoV-2 because we did not have access to a biosafety level 3 laboratory.

We developed a novel 2-step rRT-PCR specific to the minus strand of the envelope gene (Appendix, https:/ / wwwnc.cdc.gov/EID/article/27/2/20-4168-App1. pdf). First, we used strand-specific primers to convert SARS-CoV-2 RNA to complementary DNA. Then, we amplified the complementary DNA by rRT-PCR in 3 separate positive, negative, and background (no primer) reactions using the Rotor-Gene $Q$ instrument (QIAGEN, https://www.qiagen.com) (Appendix). We conducted the analytical validation during May-June 2020. We used in vitro transcribed minus- and plus-strand RNA to evaluate the linearity, precision, and lower limit of detection of the assay (Appendix).

We retrospectively collected a convenience set of upper respiratory specimens with a broad range of $C_{t}$ values. These samples had been collected and frozen from 93 inpatients and outpatients who were treated at Stanford Health Care and tested positive for SARSCoV-2 during March 12-April 9, 2020. We also reviewed the electronic medical records of the participating patients. For the prospective phase of the study, we collected upper respiratory samples from 53 consecutive patients with confirmed SARS-CoV-2 infection by standard rRT-PCR during July 31-September 4, 2020 (Appendix). Treating physicians ordered strand-specific rRT-PCR on the basis of clinical need; we used samples from these patients in the prospective phase.

We conducted analytical validation (12) and statistical analysis using Stata version 15.1 (StataCorp LLC., https:/ / www.stata.com) (Appendix). We considered a 2-tailed $p<0.05$ to be significant. This study was approved by the Stanford Institutional Review Board (protocol no. 48973).

In total, we analyzed specimens from 146 patients: 93 in the retrospective phase and 53 in the prospective 


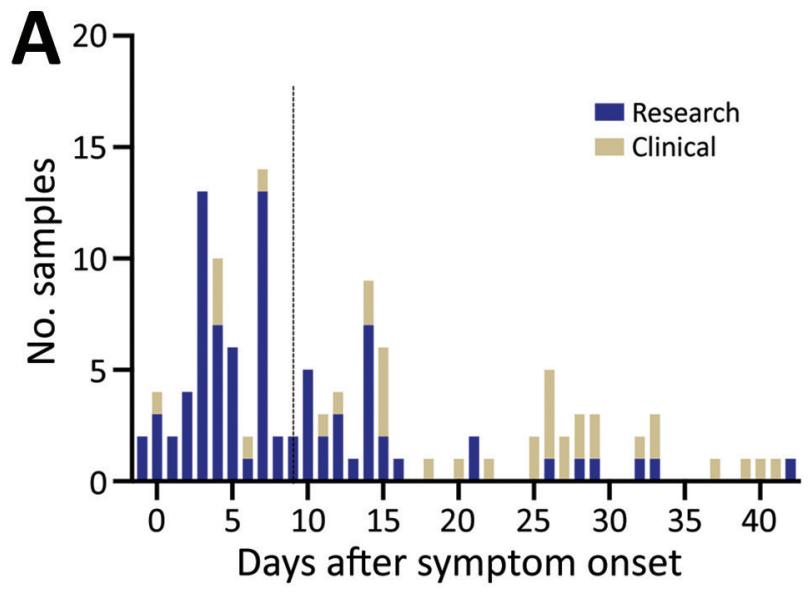

phase (Appendix Tables 3,4). The median age was 50 years (interquartile range 36-63 years); 73 (50.0\%) were women, $26(17.8 \%)$ were immunocompromised, and $30(20.5 \%)$ were admitted to the intensive care unit for coronavirus disease during the course of the study (Table 1). Samples were collected a median of 9 days (interquartile range 4-18 days) after symptom onset (Figure 1, panel A). We detected minus-strand RNA in 41 (28.1\%) patients. The median $C_{t}$ value of samples with detected minus-strand RNA (20.7) was significantly lower than those in which the minus strand was not detected (33.2; $\mathrm{p}<0.01$ ) (Figure 1, panel B). The results of this strandspecific assay were closely correlated with the standard rRT-PCR results (Figure 2, panels A, B). The ratio of minus:plus strands varied by patient within 14 days after symptom onset (Appendix Figure 2).

We detected the minus strand in 7 patients in the prospective cohort (Table 1, https://wwwnc.cdc. gov/EID/article/27/2/20-4168-T1.htm). Two of these patients were nonimmunocompromised inpatients tested $>10$ days after symptom onset, including 1 who had been asymptomatic for $>48$ hours; the $C_{t}$ values for these samples were 39.0 and 38.6. We detected minusstrand SARS-CoV-2 RNA up to 30 days after symptom onset in an immunocompromised patient with

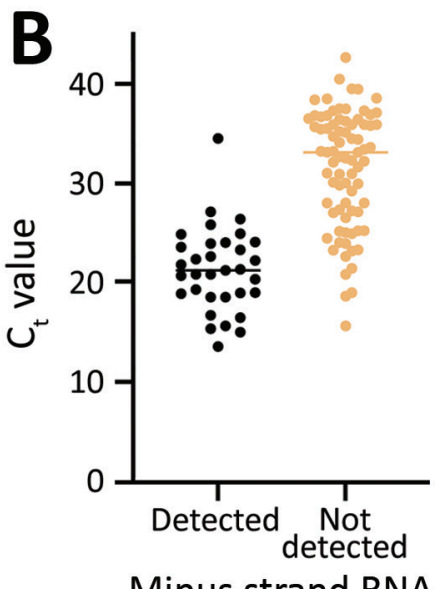

Figure 1. Frequency distribution of days between symptom onset and testing in study on strand-specific real-time reverse transcription PCR for detection of replicating severe acute respiratory syndrome coronavirus 2, California, USA, 2020. Dashed line indicates the median number of days since symptom onset. B) Distribution of standard real-time reverse transcription PCR cycle threshold values by results of strand-specific real-time reverse transcription PCR. Horizontal Minus-strand RNA line indicates median. persistent fever. For 2 patients in the prospective cohort, a negative result might have facilitated the approval of medical procedures despite prolonged positive results by standard rRT-PCR (Appendix).

\section{Conclusions}

We described the performance of a 2-step strand-specific rRT-PCR for detection of SARS-CoV-2. The assay identified viral replication in patients with persistent positive results by standard rRT-PCR, possibly facilitating clinical decision-making.

Other assays that assess intermediates of viral replication, such as subgenomic RNA, have emerged in the literature $(5,13)$. Perera et al. demonstrated high correlation between levels of presumptive SARS$\mathrm{CoV}-2$ active replication intermediates and standard rRT-PCR $C_{t}$ values (13). The standard SARS-CoV-2 rRT-PCR is appropriate for most routine clinical diagnostic applications. However, because this assay does not determine whether SARS-CoV-2 is actively replicating, it cannot infer infectiousness in samples with mid-level $C_{t}$ values (i.e., $C_{t}$ 25-35).

We detected minus-strand RNA up to 30 days after symptom onset, which is longer than the 14-day period previously reported for subgenomic RNA (13),
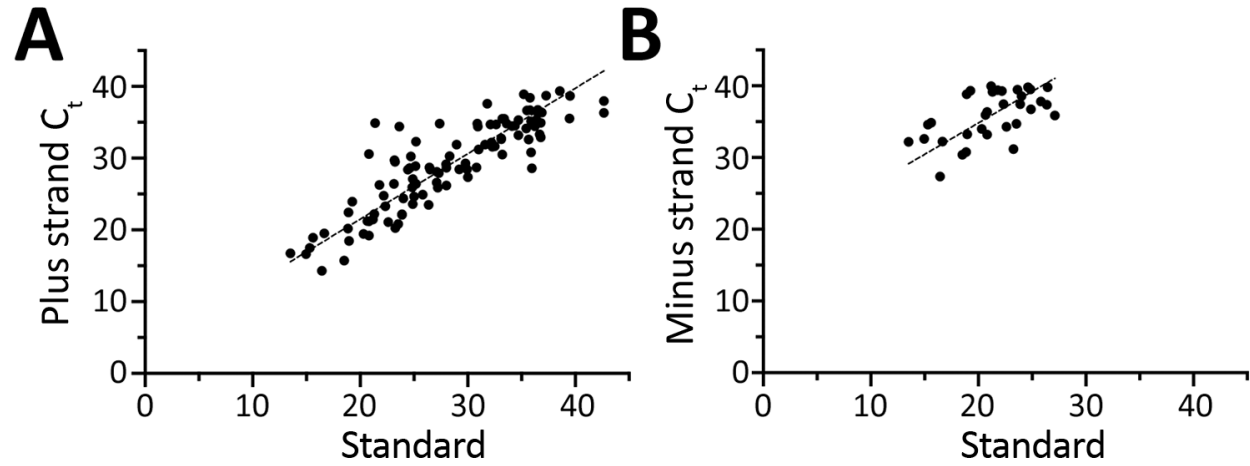

Figure 2. Deming regression analysis of $\mathrm{C}_{\mathrm{t}}$ values by strandspecific real-time reverse transcription PCR as a function of the $C_{t}$ values by standard realtime reverse transcription PCR for severe acute respiratory syndrome coronavirus 2. Results of PCR for plus strand $(A ; y=0.91 x+3.26)$ and minus strand $(B ; y=0.88 x+$ 17.30). $C_{t}$, cycle threshold. 
Table 2. Clinical characteristics of 7 patients with detected SARS-CoV-2 minus-strand RNA, California, USA, 2020*

\begin{tabular}{|c|c|c|c|c|c|c|c|c|}
\hline $\begin{array}{l}\text { Patient } \\
\text { ID }\end{array}$ & $\begin{array}{l}\text { Age, } \\
\text { y/sex }\end{array}$ & $\begin{array}{c}\text { Immuno- } \\
\text { compromised }\end{array}$ & $\begin{array}{l}\text { Test } \\
\text { order }\end{array}$ & $\begin{array}{l}\text { Cycle threshold } \\
\text { value for standard } \\
\text { rRT-PCR specific } \\
\text { to SARS-CoV-2 }\end{array}$ & $\begin{array}{c}\text { Days after } \\
\text { symptom } \\
\text { onset }\end{array}$ & $\begin{array}{c}\text { Symptomatic } \\
\text { improvement at } \\
\text { time of strand- } \\
\text { specific testing } †\end{array}$ & $\begin{array}{l}\text { Fever within } \\
24 \mathrm{~h} \text { of strand- } \\
\text { specific testing }\end{array}$ & $\begin{array}{l}\text { Minus strand detected } \\
\text { beyond CDC isolation } \\
\text { recommendations } \ddagger\end{array}$ \\
\hline 102 & $75 / \mathrm{M}$ & No & $\begin{array}{l}1 \\
2\end{array}$ & $\begin{array}{l}33.5 \\
19.7\end{array}$ & $\begin{array}{l}\text { Unclear } \\
\text { Unclear }\end{array}$ & $\begin{array}{l}\text { Unclear§ } \\
\text { Unclear§ }\end{array}$ & $\begin{array}{l}\text { No } \\
\text { No }\end{array}$ & $\begin{array}{l}\text { Unclear } \\
\text { Unclear }\end{array}$ \\
\hline 111 & $58 / \mathrm{M}$ & Yes & 1 & NAI & 26 & No & Yes & No \\
\hline 117 & $82 / \mathrm{M}$ & No & 1 & 18.5 & 12 & Unclear§ & No & Yes \\
\hline 118 & 69/M & No & 1 & 20.8 & 4 & No & Yes & No \\
\hline 127 & $61 / \mathrm{M}$ & No & 1 & 34.5 & 11 & Yes & No & Yes \\
\hline 129 & $60 / \mathrm{M}$ & Yes & $\begin{array}{l}1 \\
2\end{array}$ & $\begin{array}{l}22.6 \\
20.2\end{array}$ & $\begin{array}{l}18 \\
30\end{array}$ & $\begin{array}{l}\text { No } \\
\text { No }\end{array}$ & $\begin{array}{l}\text { Yes } \\
\text { Yes }\end{array}$ & $\begin{array}{l}\text { No } \\
\text { No }\end{array}$ \\
\hline 141 & $2 / F$ & Yes & 1 & 18.1 & NA\# & NA\# & NA\# & NA\# \\
\hline $\begin{array}{l}{ }^{*} \text { ID, iden } \\
\text { †From s } \\
\ddagger \text { Accordi } \\
\text { §Becaus } \\
\text { TQQualita } \\
\text { \#Data nc }\end{array}$ & $\begin{array}{l}\text { o reco } \\
\text { unde } \\
\text { testing } \\
\text { ailable }\end{array}$ & $\begin{array}{l}\text { A, not available; } \\
\text { set to time of tes } \\
\text { tmendations fro } \\
\text { jing condition. } \\
\text { conducted at ex } \\
\text { because patient }\end{array}$ & $\begin{array}{l}\text { RT-PCl } \\
\text { the } \\
\text { the } \mathrm{Ce}\end{array}$ & $\begin{array}{l}\text { eal-time reverse tra } \\
\text { ers for Disease Con } \\
\text { ence laboratory. }\end{array}$ & $\begin{array}{l}\text { ription PCR } \\
\text { and Prevent } \\
\text { ility. }\end{array}$ & 14). & Fespiatury & ome coronavirus 2. \\
\hline
\end{tabular}

and $8-15$ day period for viral culture $(3-6,13)$. We detected minus-strand RNA in 2 patients beyond the typical period recommended for isolation. Isolation strategies on the basis of time and symptoms are simple to apply, reduce the number of tests that need to be conducted, thus saving resources, and are probably effective at a population level (14). However, it can be challenging to determine the infectiousness of patients in certain clinical contexts, such as immunocompromised hosts with persistent viral shedding, on the basis of time and symptoms alone. Tools such as strand-specific RNA testing might be helpful in determining the infectiousness of these patients. Strand-specific testing might also help avoid delays in required procedures or treatments such as chemotherapy, which might be postponed because of SARS-CoV-2-positive PCR results.

This study has several strengths, including a large patient cohort and analytical validation. This strandspecific assay is useful because it can be adapted for routine clinical laboratory testing, does not require emergency use authorization, and reports $C_{t}$ values and strand-specific RNA detection. The study was limited by its single-center design and combination of 2 patient cohorts chosen using different selection techniques. The assay lacks viral culture data and is hampered by longer turnaround time and complexity. In future studies, we will validate this assay against SARS-CoV-2 viral culture and within a household transmission study.

In summary, we described the test performance and clinical feasibility of a strand-specific rRT-PCR assay for SARS-CoV-2. Strand-specific rRT-PCR testing might be especially useful in patients with prolonged RNA shedding. It might also supplement existing strategies for estimating infectiousness on the basis of time and symptoms. Further work is required to correlate these findings with viral culture, compare different strand-specific RNA detection methods, and to assess clinical utility in large and longitudinal patient cohorts. These findings might improve understanding of the infectiousness of SARS-CoV-2, enabling optimization of infection control measures and resource use.

\section{Acknowledgments}

We thank the staff from the Stanford Clinical Virology Laboratory for their testing of samples.

\section{About the Author}

Dr. Hogan is a medical microbiologist in the Department of Pathology, Stanford University, Palo Alto, CA. Her research interests include novel and point-of-care diagnostics, clinical impact of diagnostic methods, and global health.

\section{References}

1. Gombar S, Chang M, Hogan CA, Zehnder J, Boyd S, Pinsky BA, et al. Persistent detection of SARS-CoV-2 RNA in patients and healthcare workers with COVID-19. J Clin Virol. 2020;129:104477. https:// doi.org/10.1016/j.jcv.2020.104477

2. Sun J, Xiao J, Sun R, Tang X, Liang C, Lin H, et al. Prolonged persistence of SARS-CoV-2 RNA in body fluids. Emerg Infect Dis. 2020;26:1834-8. https:/ / doi.org/10.3201/eid2608.201097

3. Bullard J, Dust K, Funk D, Strong JE, Alexander D, Garnett L, et al. Predicting infectious severe acute respiratory syndrome coronavirus 2 from diagnostic samples. Clin Infect Dis. 2020;ciaa638. https://doi.org/10.1093/cid/ciaa638

4. La Scola B, Le Bideau M, Andreani J, Hoang VT, Grimaldier C, Colson P, et al. Viral RNA load as determined by cell culture as a management tool for discharge of SARS-CoV-2 patients from infectious disease wards. Eur J Clin Microbiol Infect Dis. 2020;39:1059-61. https:// doi.org/10.1007/ s10096-020-03913-9

5. Wölfel R, Corman VM, Guggemos W, Seilmaier M, Zange S, Müller MA, et al. Virological assessment of hospitalized patients with COVID-2019. Nature. 2020;581:465-9. https:/ / doi.org/10.1038/s41586-020-2196-x 
6. Jeong HW, Kim SM, Kim HS, Kim YI, Kim JH, Cho JY, et al. Viable SARS-CoV-2 in various specimens from COVID-19 patients. Clin Microbiol Infect. 2020;26:1520-4. https:// doi.org/10.1016/j.cmi.2020.07.020

7. Tom MR, Mina MJ. To interpret the SARS-CoV-2 test, consider the cycle threshold value. Clin Infect Dis. 2020;71:2252-4. https://doi.org/10.1093/cid/ciaa619

8. Sztuba-Solińska J, Stollar V, Bujarski JJ. Subgenomic messenger RNAs: mastering regulation of $(+)$-strand RNA virus life cycle. Virology. 2011;412:245-55. https:// doi.org/ 10.1016/j.virol.2011.02.007

9. Sawicki SG, Sawicki DL, Siddell SG. A contemporary view of coronavirus transcription. J Virol. 2007;81:20-9. https:/ / doi.org/10.1128/JVI.01358-06

10. Hogan CA, Sahoo MK, Huang C, Garamani N, Stevens B, Zehnder J, et al. Comparison of the Panther Fusion and a laboratory-developed test targeting the envelope gene for detection of SARS-CoV-2. J Clin Virol. 2020;127:104383. https://doi.org/10.1016/j.jcv.2020.104383

11. U.S. Food and Drug Administration. Stanford Health Care Clinical Virology Laboratory SARS-CoV-2 test EUA
Summary. 2020 Nov 24 [cited 2020 Dec 2]. https:/ /www.fda. gov/media/136818/download

12. Chesher D. Evaluating assay precision. Clin Biochem Rev. 2008;29:S23-6.

13. Perera RAPM, Tso E, Tsang OTY, Tsang DNC, Fung K, Leung YWY, et al. SARS-CoV-2 virus culture and subgenomic RNA for respiratory specimens from patients with mild coronavirus disease. Emerg Infect Dis. 2020;26:2701-4. https:// doi.org/10.3201/ eid2611.203219

14. U.S. Centers for Disease Control and Prevention.

Discontinuation of Transmission-Based Precautions and Disposition of Patients with COVID-19 in Healthcare Settings (Interim Guidance). 2020 [cited 2020 Sep 13]. https:/ / www.cdc.gov/coronavirus/2019-ncov/hcp/ disposition-hospitalized-patients.html

Address for correspondence: Benjamin A. Pinsky, Stanford University School of Medicine, 3375 Hillview Avenue, Room 2913, Palo Alto, CA 94304, USA; email: bpinsky@stanford.edu

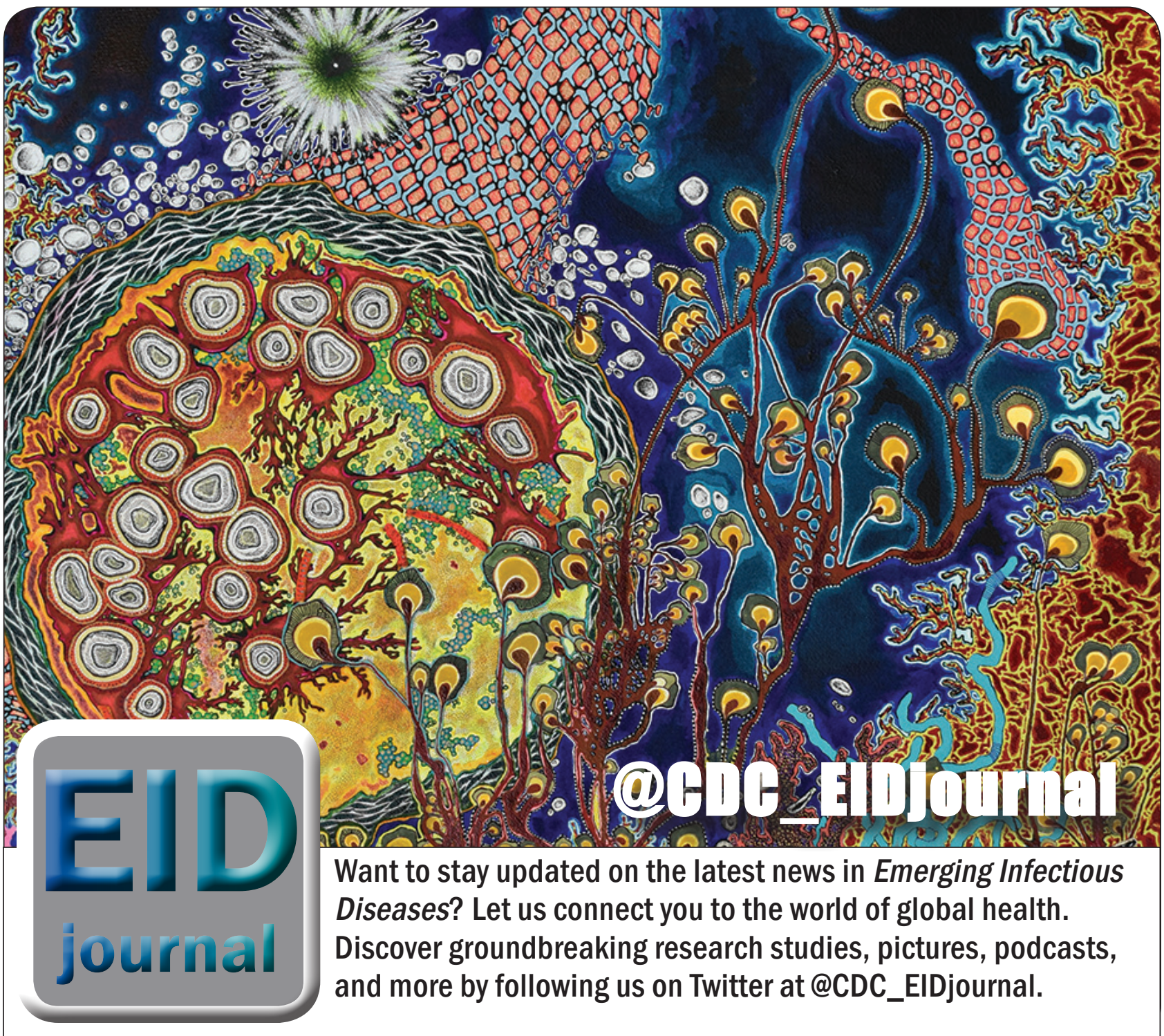

